\title{
Techniques and Problems in the Propagation of Sapogenin-bearing Yams from Stem Cuttings
}

\author{
Franklin W. Martin and Herminio Delpin ${ }^{1}$
}

\section{INTRODUCTION}

The edible true yams (chiefly Dioscorea alata L., D. esculenta (Lour.) Burk., $D$. cayenensis Lam., and $D$. rotundata Poir.) are propagated by replanting the upper portion (head piece) of the tuber containing preformed buds. In the event that additional planting material is needed, more distal tuber pieces may be used, but these do not sprout as readily as the head pieces (10). ${ }^{2}$ Stem cuttings of some species can be used to multiply a desired clone rapidly (7). The edible species very rarely produce seed. Seedlings establish themselves very slowly (9). In contrast, the sapogenin-bearing yams (2) are wild species which normally propagate themselves from seed alone.

One of the important problems in developing new cultivars from the wild yams desired as sources of steroidal sapogenins, has been the matter of propagation. Beginning with the first studies, seeds, tuber pieces, and stem cuttings were used as propagation materials (2,3). The species $D$. spiculiflora Hemsl. can be propagated easily by dividng and redividing the juvenile rosette (8). Even the leaf, if removed with the petiole and the intact pulvinus, can be stimulated to root and to develop shoots in some species (unpublished observations). The effects of techniques of propagation on costs and yields were estimated by Martin, et al. (5). It was found that propagules from stem cuttings,' although slower to establish themselves than those from tuber pieces, often outyielded the latter in sapogenin content (6). This was apparently due to higher incidence of tuber rot and lower survival of plants from tuber pieces.

The morphological aspects of rooting have been studied previously (4). The newly formed tissue in the axil of the leaf is differentiated and becomes tuber tissue. Both roots and shoots originate from this tissue rather than directly from the petiole or the stem.

A variable portion of the cuttings in previous trials developed roots but not shoots. In the experiments reported here we studied some of the variables affecting propagability of plants from stem cuttings. Preliminary trials at this and other stations had shown that single-leaf stem cuttings could be

1 Geneticist and Agricultural Research Technician, respectively, Federal Experiment Station, Crops Research Division, Agricultural Research Service, U.S. Department of Agriculture, Mayagüez, P.R.

Numbers in parentheses refer to Literature Cited, pp. 197-8. 
stimulated to root by water sprays, but that success was variable. Erratic results were associated with fungus attacks in the propagation beds, 'with the species or clones tested, and with less well-defined intrinsic factors.

\section{METHODS AND MATERIALS}

Seedlings from two open-pollinated species (Dioscorea composita Hemsl., P.I. 201783 Vera Cruz, Mexico; and D. floribunda Mart. \& Gal., FES 11566, Costa Rica; and P.I. 199766 from Guatemala) were used to test for differences in ability to propagate. Tubers of individual plants selected for high sapogenin were divided and sprouted in moist vermiculite beds in the greenhouse. The effects of fumigation with ethylene chlorohydrin which stimulates sprouting of $D$. alata (1) was tested on two accessions of $D$. floribunda and one of $D$. composita.

The tuber pieces were placed for 8 hours in sealed containers with 0.25 ml. of ethylene chlorohydrin per liter of container space. The treated tuber pieces were then planted in pots and the vines tied to bamboo stakes. Thirty stem cuttings per clone from the new shoots were planted in the greenhouse: Each cutting consisted of the petiole and the leaf with a short section of the stem from above and below the node. The stem sections and part of the petioles were covered with cleaned, screened river gravel (1/4 inch or less) and the leaf blades were supported above the gravel by horizontal wires. The beds were sprayed during 6 seconds of each minute with a water mist.

Two clones, one of $D$. composita and one of $D$. floribunda FES 11566, were selected for favorable response to propagation techniques. One hundred plants of each clone were grown in the field to provide propagating material. Effects of season, position of leaf on the stem, and treatment with a fungicide and a rooting agent were tested in a multifactorial experiment. Trials were begun during July and repeated every 3 months thereafter until four trials had been completed. Each test included all the available leaves from 25 plants of each species. The cuttings were divided into three groups representing the basal, intermediate, and terminal portions of the stem. Four pretreatments were given: 1 , Washing in tapwater; 2 , washing in tapwater and dusting the stem section with an indole butyric acid type rooting agent (Rootone); 3, washing in copper-based fungicide slurry; and 4, washing in slurry followed by dusting with rooting agent.

Cuttings were then planted in four replications arranged in random fashion. Percentage of rotted cuttings, root formation, and shoot formation were determined as 2-week intervals: One month after the first shoot appeared, the final measurements were taken. All cuttings without shoots were then randomized in two groups of four replications each. One group was treated during 8 hours with $0.25 \mathrm{ml}$. of ethylene chlorohydrin vapor per liter of space in the fumigating chamber. The other group was not treated. The 
cuttings were set in a sterile soil mixture in small pots and observed for shoot formation, survival, and dieback for two additional months.

\section{RESULTS}

When placed under a mist-spray, one-leaf stem cuttings followed distinct courses of behavior as follows: In some of the cuttings the leaves rotted soon after planting; other cuttings developed small tubers and roots at the leaf axils, and still others developed tubers, roots, and shoots. Rooting began as early as 2 to 3 weeks after planting. Shoots began to appear 4 or 5 weeks after planting. Cuttings that did not root within 60 days after treatment usually failed to do so when retained for longer periods. Clones of both species that originally rooted exceptionally well continued to respond favorably to the propagation techniques. However, cuttings taken from field-grown plants of the same clone, and grown following the same tech-

TABLE 1.-Effect of ethylene chlorohydrin treatment on the sprouting of tubers developed from single-leaf stem cultings of $\&$ selections of D. floribunda

\begin{tabular}{|c|c|c|c|c|c|}
\hline \multirow{2}{*}{ Selection } & \multirow{2}{*}{ Treatment $t^{3}$} & \multirow{2}{*}{ Cuttings treated } & \multicolumn{3}{|c|}{ Degree of sprouting after- } \\
\hline & & & 18 days & 30 days & 60 days \\
\hline $\begin{array}{l}11566 \text { (Costa Rica) } \\
11566 \text { (Costa Rica) } \\
199766 \text { (Guatemala) } \\
199766 \text { (Guatemala) }\end{array}$ & $\begin{array}{l}\text { No vapor } \\
\text { Vapor added } \\
\text { No vapor } \\
\text { Vapor added }\end{array}$ & $\begin{array}{c}\text { Number } \\
100 \\
840 \\
100 \\
1062\end{array}$ & $\begin{array}{c}\text { Percent } \\
2 \\
12 \\
0 \\
6\end{array}$ & $\begin{array}{c}\text { Percent } \\
18 \\
59 \\
13 \\
37\end{array}$ & $\begin{array}{c}\text { Percent } \\
64 \\
88 \\
37 \\
87\end{array}$ \\
\hline
\end{tabular}

1 Vapor signifies $0.25 \mathrm{ml}$. of ethylene chlorohydrin per liter of container space for 8 hours.

nique for greenhouse-grown plants, did not root as well as greenhouse-grown cuttings.

Rooted cuttings that had failed to develop shoots responded favorably to ethylene chlorohydrin treatment (table 1). Treated cuttings developed shoots more rapidly than untreated cuttings. On the other hand, in later trials treatment with $0.25 \mathrm{ml}$. ethylene chlorohydrin per liter of container space for $\mathbf{8}$ hours did not increase the rate of shooting of rooted cuttings. These unusable cuttings represented a loss of potential plants that we have not yet been able to avoid.

Because of characteristic dry-season dormancy of the vines of $D$. floribunda, we were able to make only two propagation tests with this species, one in July and another in September. The first represented a stage when many new shoots were available, and even the oldest leaves were fairly young. The second test represented a mature stage just before flowering commenced, but also characterized by rapid vegetative growth. 
Results of the trials with $D$. floribunda are given in table 2. Cuttings produced roots and shoots, or roots only, much more readily in July than in September. This is surprising, for the terminal leaves of July were of a chronological age equivalent to the terminal leaves of September.

Similar seasonal effects were observed in cuttings of $D$. composita (table 3 ). This species is more resistant to drought than $D$. floribunda, as shown by the presence of vines and leaves at all seasons in Puerto Rico. However, $D$. composita also exhibits a rest period during the dry season, when the vines do not grow vigorously, even if irrigated.

TABLE 2.-Effects of age of cuttings, season, and treatment on rooting of D. floribunda 1-leaf stem cuttings

\begin{tabular}{|c|c|c|c|c|c|c|c|c|}
\hline \multirow{2}{*}{$\begin{array}{l}\text { Date of } \\
\text { cuttings }\end{array}$} & \multirow{2}{*}{$\begin{array}{l}\text { Position of } \\
\text { cuttings }\end{array}$} & \multirow{2}{*}{$\begin{array}{l}\text { Cut- } \\
\text { tings } \\
\text { tested }\end{array}$} & \multicolumn{5}{|c|}{ Cuttings with roots and shoots- } & \multirow{2}{*}{$\begin{array}{l}\text { Cut- } \\
\text { tings } \\
\text { witt } \\
\text { roots } \\
\text { only }\end{array}$} \\
\hline & & & Rootone & Arasan & Both & Control & Mean' & \\
\hline & & Number & Percent & Percent & Percent & Percent & Percent & Percent \\
\hline $\begin{array}{c}\text { July } 8 \\
\text { Do. }\end{array}$ & $\begin{array}{l}\text { Terminal } \\
\text { Intermedi- }\end{array}$ & $\begin{array}{l}696 \\
697\end{array}$ & $\begin{array}{l}29.1 \\
11.9\end{array}$ & $\begin{array}{l}7.2 \\
6.0\end{array}$ & $\begin{array}{r}20.0 \\
4.6\end{array}$ & $\begin{array}{r}13.6 \\
9.3\end{array}$ & $\begin{array}{r}17.5 \mathrm{a} \\
8.0 \mathrm{~b}\end{array}$ & $\begin{array}{l}20.3 \\
14.1\end{array}$ \\
\hline Do. & Basal & 684 & 7.1 & 4.0 & 3.6 & 13.3 & $7.0 \mathrm{~b}$ & 12.1 \\
\hline Do. & Mean & 692 & $16.0 a$ & $5.7 \mathrm{c}$ & $9.4 b c$ & 12.1ab & 10.8 & 15.5 \\
\hline Sept. 20 & Terminal & 800 & 0.5 & 1.0 & .5 & 0 & $0.5 \mathrm{NS}$ & 18.4 \\
\hline Do. & $\begin{array}{l}\text { Intermedi- } \\
\text { ate }\end{array}$ & 800 & 0 & .5 & 1.5 & $\mathbf{0}$ & $.5 \mathrm{NS}$ & 5.9 \\
\hline Do. & Basal & 800 & 0 & 0 & 0 & .5 & $.2 \mathrm{NS}$ & 3.5 \\
\hline Do. & Mean & 800 & $.2 N S$ & $.5 N^{1}$ & $.7 \mathrm{NS} 1$ & $.2 \mathrm{NS} 1$ & 0.04 & 9.3 \\
\hline
\end{tabular}

1 Means followed by similar letters are not significantly different $(p=0.05)$. NS means not significant.

D. composita cuttings made in July developed tubers, roots, and shoots more readily than those made in September and December. The percentage developing only tubers or roots also decreased during the same season.

Differences in rootability attributable to position of a leaf were significant in both species (tables 2 and 3). Although the basal leaves of $D$. floribunda lose their ability to root, those of $D$. composita do not. The reasons for this difference between species are not evident, but may be associated with the long life or the perennial nature of the $D$. composita stem.

The treatments given to cuttings prior to rooting significantly influenced their survival and subsequent rooting (table 2). The hormone treatment increased rooting and shooting of cuttings of both species. The fungicide 
appeared to decrease rootability of cuttings of $D$. floribunda, but its effects on D. composita were not well-defined. There is a suggestion in the data of an unfavorable effect of fungicide on the terminal, but not on the basal cuttings.

The success of the July trials was significant because newer, lusher, more

TABLE 3.-Effects of age of cuttings, season, ana trealment on rooting of $D$. composita 1-leaf single-node stem cuttings

\begin{tabular}{|c|c|c|c|c|c|c|c|c|}
\hline \multirow{2}{*}{$\begin{array}{l}\text { Date of } \\
\text { cuttings }\end{array}$} & \multirow{2}{*}{$\begin{array}{l}\text { Position of } \\
\text { cuttings }\end{array}$} & \multirow{2}{*}{$\begin{array}{c}\text { Cut- } \\
\text { tings } \\
\text { tested }\end{array}$} & \multicolumn{5}{|c|}{ Cuttings with roots and shoots } & \multirow{2}{*}{$\begin{array}{l}\text { Cut- } \\
\text { tings } \\
\text { with } \\
\text { roots } \\
\text { only }\end{array}$} \\
\hline & & & Rootone & Arasan & Both & Control & Mean' & \\
\hline & & Number & Percent & Percent & Percent & Percent & Percent & Percent \\
\hline $\begin{array}{r}\text { July } 8 \\
\text { Do. }\end{array}$ & $\begin{array}{l}\text { Terminal } \\
\text { Interme- }\end{array}$ & $\begin{array}{l}720 \\
720\end{array}$ & $\begin{array}{l}29.4 \\
31.6\end{array}$ & $\begin{array}{r}6.7 \\
10.5\end{array}$ & $\begin{array}{l}22.6 \\
40.5\end{array}$ & $\begin{array}{l}7.8 \\
8.3\end{array}$ & $\begin{array}{l}16.6 \mathrm{~b} \\
22.7 \mathrm{ab}\end{array}$ & $\begin{array}{r}8.5 \\
11.9\end{array}$ \\
\hline Do. & Basal & 720 & 47.7 & 38.8 & 42.7 & 23.3 & $38.1 \mathrm{a}$ & 18.9 \\
\hline Do. & Mean & 720 & $35.9 \mathrm{a}$ & $18.7 \mathrm{~b}$ & $35.6 \mathrm{a}$ & $13.1 \mathrm{~b}$ & 25.8 & 13.1 \\
\hline $\begin{array}{c}\text { Sept. } 20 \\
\text { Do. }\end{array}$ & $\begin{array}{c}\text { Terminal } \\
\text { Interme- } \\
\text { diate }\end{array}$ & $\begin{array}{l}720 \\
720\end{array}$ & $\begin{array}{l}0.0 \\
0\end{array}$ & $\begin{array}{l}0.0 \\
1.7\end{array}$ & $\begin{array}{l}1.2 \\
1.2\end{array}$ & $\begin{array}{l}0.0 \\
0\end{array}$ & $\begin{array}{r}0.3 \mathrm{NS}^{1} \\
.8 \mathrm{NS}^{1}\end{array}$ & $\begin{array}{l}2.9 \\
2.9\end{array}$ \\
\hline Do. & Basal & 720 & .6 & .0 & .0 & .6 & $.3 N S^{1}$ & 2.8 \\
\hline Do. & Mean & 720 & $0.2 \mathrm{NS}^{1}$ & $0.6 \mathrm{NS}^{1}$ & $.8 \mathrm{NS}^{\prime}$ & $0.2 \mathrm{NS}^{1}$ & 0.4 & 2.9 \\
\hline $\begin{array}{c}\text { Dec. } 19 \\
\text { Do. }\end{array}$ & Terminal & 720 & 0 & .0 & .0 & 0.0 & $\begin{array}{ll}0 & N^{2} \\
N\end{array}$ & $\begin{array}{l}0.0 \\
0\end{array}$ \\
\hline & diate & 720 & 0 & 0 & 0 & 0 & $2 \pi$ & \\
\hline Do. & Basal & 720 & 0 & $\mathbf{0}$ & $\mathbf{0}$ & $\mathbf{0}$ & 0 NS 1 & $\mathbf{0}$ \\
\hline Do. & Mean & 720 & $0.0 \mathrm{NS} 1$ & $0.0 \mathrm{NS}^{2}$ & $0.0 \mathrm{NS}$ & $0.0 \mathrm{NS}^{1}$ & 0.0 & $\mathbf{0}$ \\
\hline Mar. 15 & Terminal & 360 & $\mathbf{0}$ & $\mathbf{0}$ & 1.1 & $\mathbf{0}$ & $0.3 \mathrm{NS}$ & 12.5 \\
\hline Do. & $\begin{array}{c}\text { Interme- } \\
\text { diate }\end{array}$ & 360 & 0 & 1.1 & 0 & 1.1 & $.5 \mathrm{NS}$ & 15.3 \\
\hline Do. & Basal & 360 & 1.1 & 1.1 & 1.1 & $\mathbf{0}$ & $.8 \mathrm{NS}$ & 11.4 \\
\hline Do. & Average & 360 & $0.4 \mathrm{NS}$ & $0.7 \mathrm{NS}$ & $0.7 \mathrm{NS}$ & $0.4 \mathrm{NS}$ & 0.5 & 13.1 \\
\hline
\end{tabular}

1 Not significant.

succulent leaves root easier during this season, although this was not confirmed in replicated tests.

\section{DISCUSSION AND CONCLUSIONS}

The propagation of the sapogenin-bearing Dioscoreas by stem-cuttings represents a departure from the normal mode of reproduction of these 
species. In the process inactive meristematic tissue is activated by the propagation techniques. It is obvious that the stage of maturity of the tissue itself influences ease of propagation. Of the variables tested, season of the year apparently is the most important, because it may affect either the readiness of the plant materials themselves or the conditions under which propagation is attempted. Although not adequately evaluated in this study, the leaves from greenhouse-grown plants germinate more easily than those from field-grown plants. The position of cuttings on the vine also influences propagability. This factor is an expression of relative age of the leaf. Although the two species studied showed opposite responses with position, it must be remembered that the species have somewhat different seasons and growth rates, and are therefore not strictly comparable. Finally, rooting agents applied to the stem may stimulate growth responses in receptive cuttings.

All of the above factors contribute to new, succulent vegetative growth. It is probable that this juvenility and vigor lead to ease of propagation. Although these generalities do not fully explain what constitutes a state of "readiness" in a cutting, they do help in making recommendations for improved practices.

Plants to be used as sources of leaf cuttings can best be propagated in the field where they develop greater size and vigor. Pieces from the tubers can then be propagated during the early rainy season in a greenhouse or screenhouse where the soil is rich, temperatures are fairly constant, and moisture is adequate. Cuttings can be made from all available leaves. The cuttings can be treated with a rooting agent. If good sanitation is practiced, no fungicide is necessary. The cuttings should be treated by an intermittent mist-spray schedule which keeps them damp but not running wet. The propagation bed should be well-aerated, well-drained, and partly shaded. Under these conditions, maximum rooting and shooting can be expected. The use of ethylene chlorohydrin to stimulate shooting of rooted cuttings may be tried. With $D$. composita and $D$. floribunda a variable percentage of rooted but shootless cuttings can be expected in any propagation study.

\section{SUMMARY}

Sapogenin-bearing yams, the sources of steroid hormones, were propagated by leaf-stem cuttings, which is a new method of propagation for this type of yam. Experiments were conducted to determine the effect of such factors as the season of the year, position of the leaf on the stem, and treatments with hormones and fungicides on the propagation of two species of medicinal yams ( $D$. composita and $D$. floribunda) from leaf-stem cuttings. It was found that an important factor in the propagation from leaf-stem is the use of young, vigorous, succulent leaves. Leaves produced during the 
spring have these characteristics. Cuttings can be made from all available leaves. It was also found that hormones stimulate root growth and that, if good sanitation is practiced, fungicides are not necessary. Treatments with ethylene chlorohydrin in sealed containers, at the rate of $0.25 \mathrm{ml}$. per liter of air space, stimulate shoot growth. The two species tested are completely different in behavior with respect to their ability to respond to the treatments applied. The cuttings should be treated by an intermittent mist-spray schedule which keeps them damp. Differences in rootability resulting from the position of the leaf on the stem were significant in both species. The treatments given to cuttings prior to rooting influenced their survival and rooting.

\section{RESUMEN}

Los ñames medicinales, los cuales son fuentes de hormonas esteroides (cortisona), se propagan mediante esquejes de tallo, lo cual constituye un nuevo método para la propagación de estas especies de ñames. En los experimentos llevados a cabo en los cuales se considerb la estación del año, la posición de la hoja en el tallo y el tratamiento con hormonas y fungicidas en la propagación por esquejes de dos especies de ñames medicinales, la $D$. composita y $D$. floribunda, se encontró que el factor más importante es el uso de hojas jóvenes, vigorosas y suculentas. Las hojas que se producen durante la primavera tienen estos requisitos. Pueden prepararse esquejes de todas las hojas accesibles. Se descubrió que las hormonas estimulan el crecimiento de las raíces, y que los fungicidas no son necesarios, si se pone en práctica un buen plan de saneamiento. Los tratamientos con clorohidrina de etileno en recipientes cerrados, a razón de $0.25 \mathrm{ml}$. por litro de espacio, estimulan el crecimiento de los tallos. Las dos especies bajo investigación se comportaron de manera distinta, con respecto a su habilidad para responder a los tratamientos. Es necesario que los esquejes de tallo se traten siguiendo una aplicación regulada de llovizna artificial intermitente de modo que se mantengan húmedos. Las diferencias en cuanto al desarrollo de las raíces según la posición de la hoja en el tallo, fueron significativas en ambas especies. Los tratamientos que se les aplicaron a los esquejes, antes del desarrollo de las raíces, influyeron sobre la sobrevivencia y la producción de las mismas.

\section{LITERATURE CITED}

1. Cambell, J. S., Chukwueke, V. O., Teriba, F. A., Ho-A-Shu, H. V. S., Some physiological investigations into the White Lisbon yam (Dioscorea alata $L$.) I., The breakage of the rest period in tubers by chemical means, Emp. J. Exp. Agri. 30 (118): 108-14, 1962.

2. Correll, D. S., Shubert, B. G., Gentry, H. S., and Hawley, W. O., The search for plant precursors of cortisone, Econ. Bol. $\theta$ (4): 305-75, 1955. 
3. Kennard, W. C. and Morris, M. P., Influence of cultural practices on tuber yields and sapogenin content of Dioscorea floribunda, Agron.J. 48 (11): 485-87, 1956.

4. Martin, F. W., \& Ortiz, S., Origin and anatomy of the tubers of Dioscorea floribunda and D. spiculiflora, Bol. Gaz. 124 (6): 416-21, 1963.

5. Martin, F. W., Cabanilla, E., and Gaskins, M. H., Economics of the sapogeninbearing yam as a crop plant in Puerto Rico, J. Agr. Univ. P. R. 60 (1): 53-64, 1966.

6. Martin, F. W. and Delpin, $H$, The influence of some soil and climatic factors on sapogenin yields of Dioscorea, J. Agr. Univ. P.R. 61 (3): 261-65, 1967.

7. Njoku, E., The propagation of yams (Disocorea spp) by vine cuttings, J.W. Afr. Sci. Ass. 8 (1): 29-32, 1963.

8. Preston, W. H., Jr., and Haun, J. R., Factors involved in the vegetative propagation of Dioscorea spiculiflora Hemsl. from vines, Proc. Amer. Soc. Hort. Sci. 80 417-29, 1962.

9. Waitt, A. W., Rept. Dept. Agr. Res. Nigeria, 1957-58: 18-19, Lagos: Fed. Govt. Printer, 1959.

10. - Yams, Dioscorea species, Field Crop Abstracts, 16 (3): 145-57, 1963. 